\title{
Angiostrongylus costaricensis infection in Martinique, Lesser Antilles, from 2000 to 2017
}

\author{
Céline Dard ${ }^{2,3, a,{ }^{*}}$, Duc Nguyen ${ }^{4,5, a}$, Charline Miossec $^{1}$, Katia de Meuron $^{6}$, Dorothée Harrois ${ }^{7}$, Loïc Epelboin $^{5,8}$, \\ André Cabié ${ }^{4,9,10}$, and Nicole Desbois-Nogard ${ }^{1, *}$ \\ ${ }^{1}$ Laboratoire de Parasitologie-Mycologie-Sérologies Bactériennes et Parasitaires, CHU de la Martinique, 97200 Fort-de-France, \\ France \\ ${ }^{2}$ Laboratoire de Parasitologie-Mycologie, CHU Grenoble Alpes, 38700 Grenoble, France \\ ${ }^{3}$ Institute for Advanced Biosciences (IAB), INSERM U1209 - CNRS UMR5309, Université Grenoble Alpes, 38700 Grenoble, \\ France \\ ${ }^{4}$ Service de Maladies Infectieuses et Tropicales et Médecine Polyvalente, CHU de la Martinique, 97200 Fort-de-France, France \\ ${ }^{5}$ EA3593, Ecosystèmes Amazoniens et Pathologie Tropicale, Université de la Guyane, 97306 Cayenne, France \\ ${ }_{7}^{6}$ Service de Pédiatrie, Maison de la Femme de la Mère et de l'Enfant, 97200 Fort-de-France, France \\ 7 Laboratoire de Biologie Médicale, Centre Hospitalier de Basse-Terre, 97109 Basse-Terre, Guadeloupe, France \\ ${ }^{8}$ Unité des Maladies Infectieuses et Tropicales, Centre Hospitalier Andrée Rosemon, 97306 Cayenne, France \\ ${ }^{9}$ CIC Antilles-Guyane, INSERM 1424, Centre Hospitalier Andrée Rosemon, 97306 Cayenne, France \\ ${ }^{10}$ Université des Antilles, EA4537, 97200 Fort-de-France, France
}

Received 5 February 2018, Accepted 22 March 2018, Published online 10 April 2018

\begin{abstract}
Human abdominal angiostrongyliasis (HAA) is a parasitic disease caused by the accidental ingestion of the nematode Angiostrongylus costaricensis in its larval form. Human infection can lead to severe ischemic and inflammatory intestinal lesions, sometimes complicated by life-threatening ileal perforations. Only one case had been reported in Martinique, an Island in the French Antilles, in 1988. We retrospectively reviewed the medical charts of patients diagnosed with abdominal angiostrongyliasis at the University Hospital of Martinique between 2000 and 2017. The objectives of this study were to evaluate the incidence and perform a descriptive analysis of the clinical, biological, radiological, and histopathological features of HAA in Martinique. Two confirmed cases and two probable cases were identified in patients aged from 1 to 21 years during the 18year period, with an estimated incidence of 0.2 cases per year $(0.003$ case $/$ year $/ 100.000$ inhabitants $($ IC $95 \%=$ 0.00-0.05)). All patients presented with abdominal pain associated with high blood eosinophilia (median: $7.24 \mathrm{G} / \mathrm{L}$ [min $4.25 ; \max 52.28 \mathrm{G} / \mathrm{L}]$ ). Two developed ileal perforation and were managed by surgery, with diagnostic confirmation based on histopathological findings on surgical specimens. The other two cases were probable, with serum specimens reactive to Angiostrongylus sp. antigen in the absence of surgery. All cases improved without sequelae. The description of this case series highlights the need to increase awareness of this life-threatening disease in the medical community and to facilitate access to specific diagnostic tools in Martinique. Environmental and epidemiological studies are needed to broaden our knowledge of the burden of this disease.
\end{abstract}

Keywords: Angiostrongylus costaricensis, Abdominal angiostrongyliasis, helminth, intestinal parasitosis, eosinophilic ileocolitis, Martinique, French Antilles, Lesser Antilles, Caribbean

Résumé-Infections par Angiostrongylus costaricensis à la Martinique, Antilles, de 2000 à 2017. L'angiostrongylose abdominale humaine (AAH) est une maladie parasitaire causée par l'ingestion accidentelle du nématode Angiostrongylus costaricensis sous sa forme larvaire. L'infection humaine peut conduire à des lésions intestinales ischémiques et inflammatoires sévères, parfois compliquées par des perforations iléales menaçant le pronostic vital. Un seul cas avait été signalé en Martinique, une île des Antilles françaises, en 1988. Nous avons revu rétrospectivement les dossiers médicaux des patients ayant reçu un diagnostic

\footnotetext{
*Corresponding authors:

nicole.desbois-nogard@chu-martinique.fr;

cdard@chu-grenoble.fr

a These authors contributed equally to this work.
}

This is an Open Access article distributed under the terms of the Creative Commons Attribution License (http://creativecommons.org/licenses/by/4.0), which permits unrestricted use, distribution, and reproduction in any medium, provided the original work is properly cited. 


\begin{abstract}
d'angiostrongylose abdominale au CHU de la Martinique entre 2000 et 2017. Les objectifs de cette étude étaient d'évaluer l'incidence et effectuer une analyse descriptive des caractéristiques cliniques, biologiques, radiologiques et histopathologiques de l'AAH en Martinique. Deux cas confirmés et deux cas probables ont été identifiés chez des patients âgés de 1 à 21 ans au cours de la période de 18 ans, avec une incidence estimée à 0,2 cas par an $(0,003$ cas / an / 100000 habitants (IC95\% =0,00-0,05)). Tous les patients présentaient une douleur abdominale associée à une éosinophilie sanguine élevée (médiane: 7,24 G/L [min 4,25; max 52,28 G / L]). Deux ont développé une perforation iléale et ont été traités par chirurgie, avec une confirmation diagnostique basée sur les résultats histopathologiques sur des échantillons chirurgicaux. Les deux autres cas étaient probables, avec des échantillons sériques réagissant aux antigènes d'Angiostrongylus sp. en l'absence de chirurgie. Tous les cas se sont améliorés sans séquelles. La description de cette série de cas souligne la nécessité de sensibiliser davantage la communauté médicale à cette maladie potentiellement mortelle et de faciliter l'accès à des outils diagnostiques spécifiques en Martinique. Des études environnementales et épidémiologiques sont nécessaires pour élargir nos connaissances sur cette parasitose.
\end{abstract}

\section{Introduction}

Human abdominal angiostrongyliasis (HAA) is a zoonotic disease caused by a nematode, Angiostrongylus costaricensis Morera \& Céspedes, 1971 [44]. The definitive hosts are rodents of the Cricetidae, Heteromyidae, and Muridae families $[19,40,60,62]$. Adult nematodes reside in the mesenteric arterial system of wild rodents, in which females lay eggs that generate first-stage larvae (L1), which are shed in the rodents' feces. Larval maturation to the third-stage (L3) occurs in intermediate hosts, mainly slugs from the families Veronicellidae and Limacidae $[11,21,46,62]$. Human infection is accidental and occurs by ingesting third-stage larvae (L3) from mollusks or vegetables contaminated with their slime [43]. Once ingested, the larvae invade intestinal tissues, reach sexual maturity, and release eggs in the ileo-cecal mesenteric arteries, causing eosinophilic enteritis in humans [66].

A. costaricensis was first discovered in the mesenteric arteries of humans in Costa Rica in 1967 [7,45], followed by the description of adult worms in the rodent Sigmodon hispidus in 1971 [44]. A. costaricensis is now found from Texas [64] southward to Argentina [52], including Honduras [27,58], Venezuela [23,69], Mexico [70], Brazil [71], Colombia [35], Nicaragua [12], El Salvador [68], Ecuador [30], Guatemala [28], Panama [63], Peru, [60] and probably French Guiana [65]. The disease is a public health problem in South America, in particular in Costa Rica, where it affects $12 / 100,000$ persons, with approximately 500 new cases each year [43]. Some sero-epidemiological studies in South America have shown strong seroprevalence rates in humans, i.e., from 29.8 to $66.0 \%$ in endemic areas of Southern Brazil. This implies numerous asymptomatic infections [17] and a far broader distribution of the parasite in the Americas than previously believed [34]. In contrast, HAA is rarely reported in the Antilles and only six sporadic cases have been described since 1974 (Table 2). Among them, one was reported in Martinique, an island in the French Antilles.

The main objective of this study was to evaluate the incidence of symptomatic HAA cases in Martinique. The secondary objective was to perform a descriptive analysis of the clinical, biological, radiological, and histopathological features of these cases.

\section{Materials and Methods \\ Setting}

Martinique is a French Overseas Department in the Antilles, with a population of 380,877 inhabitants as of January $1^{\text {st }}, 2015$ (INSEE census, www.insee.fr). It has a tropical climate, with a rainy season from June to November and a dry season from December to May.

\section{Study design}

A retrospective monocentric observational study was performed in the University Hospital of Martinique between January 1, 2000 and December 31, 2017. Data were extracted from the hospital data information system (PMSI), in which classification is based on the International Classification of Diseases, Tenth Revision (ICD-10). Hospital data codes for HAA (B813) were selected from the PMSI databases. Demographic data, abdominal imaging, biological results, clinical features, and outcomes were anonymously and retrospectively collected from the medical charts according to the legal and ethical guidelines of the French National Committee on Data Protection (CNIL). Serological assays to detect IgG against Angiostrongylus sp. were performed at the Swiss Tropical and Public Health Institute, Basel, Switzerland. Sera were first tested using the ELISA helminth screening test (detecting Toxocara sp., Trichinella sp., Echinococcus sp., Fasciola sp., Filaria, Schistosoma sp., and Strongyloides sp.) followed by a western blot using antigens derived from A. cantonensis adult worms [13].

\section{Case definition}

We defined a confirmed case as a patient with clinical symptoms and biological results consistent with HAA (fever, abdominal tenderness, and blood eosinophilia) and histopathological findings of HAA (identification of worms, eggs, or larvae in the intestinal wall). A probable 
Table 1. Clinical characteristics of the four patients with confirmed (cases 1 and 2) and probable (cases 3 and 4 ) Angiostrongylus costaricensis infection in Martinique. A. fulica: Achatina fulica, CRP: C-reactive protein, CSF: Cerebrospinal fluid, CT scan: Computerized axial tomography, Dx: x Days, EBV: Epstein-Barr virus, IV: intra-venous, L. aurora: Limicolaria aurora, ND: No Data.

\begin{tabular}{|c|c|c|c|c|}
\hline Case & 1 & 2 & 3 & 4 \\
\hline \multicolumn{5}{|c|}{ Background data } \\
\hline Year of diagnosis & 2000 & 2001 & 2016 & 2017 \\
\hline Season & August, rainy season & October, rainy season & November, rainy season & February, dry season \\
\hline Sex & $\mathrm{M}$ & $\mathrm{F}$ & $\mathrm{F}$ & $\mathrm{M}$ \\
\hline Age & 12 months & 12 months & 14 years & 21 years \\
\hline $\begin{array}{l}\text { Area of residence (city, } \\
\text { district) }\end{array}$ & Le Lamentin & Saint-Esprit & Le Robert & Fort-de-France \\
\hline Living conditions & Residential area & Residential area & Residential area & ND \\
\hline Medical history & None & None & None & None \\
\hline $\begin{array}{l}\text { Reported contact with } \\
\text { mollusks }\end{array}$ & $\begin{array}{l}\text { None, but numerous slugs } \\
\text { of und. species in the } \\
\text { garden }\end{array}$ & $\begin{array}{l}\text { None, but numerous slugs } \\
\text { of und. species and snails } \\
\text { ( } \text {. fulica, L. aurora, ) in } \\
\text { the garden } \\
\text { Clinical picture }\end{array}$ & $\begin{array}{l}\text { None, but numerous } \\
\text { snails ( } A \text {. fulica, } L . \\
\text { aurora) at school }\end{array}$ & $\mathrm{ND}$ \\
\hline $\begin{array}{l}\text { Duration of symptoms } \\
\text { before admission }\end{array}$ & 1 month & 2 weeks & 1 month & 24 hours \\
\hline $\begin{array}{l}\text { Extra-digestive } \\
\text { symptoms }\end{array}$ & $\begin{array}{l}\text { Irritability, moderate fever } \\
\left(38.5^{\circ} \mathrm{C}\right)>7 \text { days }\end{array}$ & $\begin{array}{l}\text { Decreased reactivity, fever } \\
\left(38.0^{\circ} \mathrm{C}\right)>14 \text { days }\end{array}$ & Fever $>14$ days; & Fever $\left(39.0^{\circ} \mathrm{C}\right)$ \\
\hline Loss of weight & $\begin{array}{l}3.2 \% \text { in } 7 \text { days } \\
\text { (basal weight } 9120 \mathrm{~g} \text { ) }\end{array}$ & $6 \%$ in 15 days & None & None \\
\hline Digestive symptoms & $\begin{array}{l}\text { Anorexia, emesis, right iliac } \\
\text { fossa pain, diarrhea, trails } \\
\text { of blood in feces, } \\
\text { dehydration }\end{array}$ & $\begin{array}{l}\text { c Anorexia, right iliac fossa } \\
\text { pain, watery diarrhea, } \\
\text { emesis }\end{array}$ & $\begin{array}{l}\text { Severe right iliac fossa } \\
\text { pain, emesis }\end{array}$ & $\begin{array}{l}\text { Abdominal pain in } \\
\text { suprapubic region, } \\
\text { diarrhea, emesis }\end{array}$ \\
\hline \multicolumn{5}{|c|}{ Laboratory results } \\
\hline Initial WBC $\left(10^{9} / \mathrm{L}\right)$ & 25.5 & 19.1 & 19.8 & 63.3 \\
\hline $\begin{array}{l}\text { Max eosinophilia } \\
(\mathrm{G} / \mathrm{L}(\%))\end{array}$ & $4.25(17)$ & $4.68(19)$ & $9.8(49.2)$ & $52.28(82.6)$ \\
\hline $\begin{array}{l}\text { Initial hemoglobin }(g / \\
d L)\end{array}$ & 9.6 & 6.8 & 15.5 & 15.5 \\
\hline $\mathbf{C R P}(\mathrm{mg} / \mathrm{L})$ & 95 & 94.5 & 3 & 223 \\
\hline $\begin{array}{l}\text { Liver, renal, hemostatic } \\
\text { parameters }\end{array}$ & Normal & Normal & Normal & Normal \\
\hline $\begin{array}{l}\text { Microbiological } \\
\text { analyses }\end{array}$ & $\begin{array}{l}\text { Blood, urine, CSF cultures: } \\
\text { negative }\end{array}$ & $\begin{array}{l}\text { Negative blood culture, } \\
\text { positive urine culture }(E \text {. } \\
\left.\text { coli } 10^{5} \mathrm{UFC} / \mathrm{ml}\right)\end{array}$ & None & $\begin{array}{l}\text { Blood and urine } \\
\text { cultures: negative }\end{array}$ \\
\hline $\begin{array}{l}\text { Angiostrongylus } \\
\text { cantonensis } \text { serology }\end{array}$ & None & None & $\begin{array}{l}\text { Positive } \\
\text { (IgG, Western-Blot) }\end{array}$ & $\begin{array}{l}\text { Positive } \\
\text { (IgG, Western-Blot) }\end{array}$ \\
\hline $\begin{array}{l}\text { Helminth ELISA } \\
\text { screening test }^{\mathrm{a}}\end{array}$ & None & None & Negative & Negative \\
\hline Other parasitic serology & y None & $\begin{array}{l}\text { Schistosomiasis, } \\
\text { toxocariasis: negative }\end{array}$ & Toxocariasis: negative & $\begin{array}{l}\text { Schistosomiasis, } \\
\text { toxocariasis: } \\
\text { negative }\end{array}$ \\
\hline $\begin{array}{l}\text { Parasitological } \\
\text { examination of feces }\end{array}$ & $\begin{array}{l}\text { Few altered embryonated } \\
\text { eggs of helminths \& } \\
\text { numerous Charcot Leyden } \\
\text { crystals (D4 after surgery). } \\
\text { Abdom }\end{array}$ & $\begin{array}{l}\text { Negative, numerous } \\
\text { Charcot Leyden crystals } \\
\text { ninal imaging \& surgery }\end{array}$ & Negative (3 times) & Negative (2 times) \\
\hline Abdominal imagery & $\begin{array}{l}\text { Ultrasound: dilated ileum, } \\
\text { peritoneal exudate in the } \\
\text { right iliac fossa, X-rays: } \\
\text { distended left colic flexure } \\
\text { (Fig. 1) }\end{array}$ & $\begin{array}{l}\text { X-rays (Fig. 3): } \\
\text { pneumoperitoneum under } \\
\text { right hypochondria }\end{array}$ & $\begin{array}{l}\text { Ultrasound: colon wall } \\
\text { thickening, mild } \\
\text { intraperitoneal effusion }\end{array}$ & $\begin{array}{l}\text { CT scan: } \\
\text { micronodular } \\
\text { pulmonary pattern, } \\
\text { peripheral } \\
\text { lymphadenopathy. }\end{array}$ \\
\hline
\end{tabular}


Table1. (continued).

\begin{tabular}{|c|c|c|c|c|}
\hline Case & 1 & 2 & 3 & 4 \\
\hline $\begin{array}{l}\text { Exploratory } \\
\text { laparotomy/ } \\
\text { laparoscopy }\end{array}$ & $\begin{array}{l}\text { Laparotomy (D3): ischemic } \\
\text { and congestive ileum, } \\
\text { necrotic areas, mesenteric } \\
\text { lymph node enlargement }\end{array}$ & Laparotomy (D50) & None & None \\
\hline Surgical procedure & $\begin{array}{l}18 \mathrm{~cm} \text { long ileal resection } \\
\text { and anastomosis }\end{array}$ & $\begin{array}{l}16 \mathrm{~cm} \text { long ileal resection } \\
\text { (distal ileon }+ \text { ileo-cecal } \\
\text { valve) with } 3 \mathrm{~cm} \text { of healthy } \\
\text { surgical resection margins } \\
\text { and anastomosis }\end{array}$ & None & None \\
\hline
\end{tabular}

Macroscopic aspect

Histological examination of surgical specimen

\section{Diagnosis of angiostrongyliasis}

\section{Concomitant \\ infections \\ Symptomatic treatment and treatment for co- infections}

\section{Anthelmintic treatment}

Length of
hospitalization

Clinical improvement

Decline of eosinophilia

Sequelae \& clinical outcome

${ }^{a}$ Helminth ELISA screening test simultaneously detects seven different species of tissue helminths (Toxocara sp., Trichinella sp.,

Echinococcus sp., Fasciola sp., Filaria, Schistosoma sp. and Strongyloides sp.)

Histology of resected specimen

\begin{tabular}{|c|c|c|c|}
\hline $\begin{array}{l}\text { Rigid, ulcerated, and } \\
\text { hemorrhagic pattern }\end{array}$ & $\begin{array}{l}\text { Surgical specimen } \\
\text { agglutinated, necrotized, } \\
\text { and covered with false } \\
\text { membranes }\end{array}$ & None & None \\
\hline
\end{tabular}

eosinophilic infiltration of granulomas with giant the intestinal mucosa, cells, plasmocytes and 60 to $80 \mu \mathrm{m}$ long and eosinophilic cells, $A$. mostly embryonated ovoid costaricensis eggs eggs within the granulomas (Fig. 4A), larvae (Fig. 4B) with macrophages and eosinophils, thrombotic phenomena in muscular and adults in the lumen of some vessels (Fig. 4C and 4D)

arteria caused by

degenerated 140 to $180-\mu \mathrm{m}$

long $A$. costaricensis adults (Fig. 2A and 2B).

\section{Diagnosis \& Medical care}

Histology of resected ileal Histology of resected ileal Probable with positive Probable with specimen (D3 after hospitalization) specimen (D50 after hospitalization)

A. cantonensis serology positive $A$.

None

After surgery: blood transfusion, proper hydration, analgesia and nutrition, antibiotics (ceftriaxone, metronidazole)

Thiabendazole $75 \mathrm{mg} / \mathrm{kg} /$ day (10 days)

25 days

3 weeks after surgery

$1.41 \mathrm{G} / \mathrm{L}$ D18 after hospitalization

EBV primary infection, (D30 after cantonensis serology hospitalization) urinary tract infection IV antibiotics for urinary Acetaminophen, tract infection (cefotaxime, domperidone netilmicin),

After surgery: blood

transfusion, parenteral rehydration, antipyretics, antibiotics (cefotaxime, amikacin, metronidazole) Flubendazole empirical treatment (3 days) before diagnosis, thiabendazole (5 days)

Ivermectin (18 $\mathrm{mg}$ in $50 \mathrm{mg} / \mathrm{kg} /$ day (5 days)

after diagnosis

2 hospitalizations $\quad 7$ days 10 days

$1^{\text {st }}: 16$ days

$2^{\text {nd }}: 37$ days

\section{Outcome}

3 weeks after surgery

1.17 G/L D71 after first hospitalization

Recovery

\section{None}

Acetaminophen
2 weeks after

Regression of anthelmintic treatment symptoms $0.40 \mathrm{G} / \mathrm{L} 10$ months $2.0 \mathrm{G} / \mathrm{L}$ D80 after after hospitalization hospitalization Recovery
Recovery 
Table 2. Abdominal angiostrongyliasis in the Antilles. Literature review of the six HAA cases described in the Greater and Lesser Antilles before the description of the new confirmed and probable HAA cases in Martinique. ND: No Data.

\begin{tabular}{|c|c|c|c|c|c|c|}
\hline Case & 1 & 2 & 3 & 4 & 5 & 6 \\
\hline \multicolumn{7}{|c|}{ Background data } \\
\hline Island & $\begin{array}{l}\text { Martinique, } \\
\text { Lesser Antilles }\end{array}$ & Guadeloupe, & Lesser Antilles & $\begin{array}{l}\text { Dominican } \\
\text { Republic, } \\
\text { Greater } \\
\text { Antilles }\end{array}$ & $\begin{array}{l}\text { Puerto Rico, } \\
\text { Greater } \\
\text { Antilles }\end{array}$ & $\begin{array}{l}\text { Dominica, } \\
\text { Lesser Antilles }\end{array}$ \\
\hline Reference & {$[24]$} & & 26] & {$[59]$} & {$[47]$} & {$[50]$} \\
\hline Year of diagnosis & 1984 & 1987 & 1989 & 1989 & 1993 & 1997 \\
\hline Season & Rainy season & ND & ND & ND & ND & ND \\
\hline Sex & M & $\mathrm{F}$ & M & M & M & $\mathrm{M}$ \\
\hline Age & 16 months & 20 months & 5 years & 41 years & 42 years & ND (student) \\
\hline $\begin{array}{l}\text { Area of residence } \\
\text { (city) }\end{array}$ & $\begin{array}{l}\text { Martinique } \\
\text { (Sainte-Luce) }\end{array}$ & $\mathrm{ND}$ & ND & $\mathrm{ND}$ & $\begin{array}{l}\text { Pennsylvania } \\
\text { for } 2 \text { months, } \\
\text { Puerto Rico } \\
\text { the past } \\
3 \text { years }\end{array}$ & $\begin{array}{l}\text { US student } \\
\text { living in } \\
\text { Dominica }\end{array}$ \\
\hline Living conditions & $\begin{array}{l}\text { Rural area, } \\
\text { house without } \\
\text { water or } \\
\text { electricity }\end{array}$ & $\begin{array}{l}\text { Rural \& } \\
\text { residential } \\
\text { area, presence } \\
\text { of rats. } \\
\text { Wealthy } \\
\text { family }\end{array}$ & $\begin{array}{l}\text { Rural area, no } \\
\text { water or } \\
\text { electricity, } \\
\text { presence of } \\
\text { rats }\end{array}$ & ND & ND & ND \\
\hline $\begin{array}{l}\text { Travel outside of } \\
\text { island of residence }\end{array}$ & No & $\mathrm{ND}$ & ND & ND & $\begin{array}{l}\text { Yes, Puerto } \\
\text { Rico } 2 \text { months } \\
\text { before }\end{array}$ & ND \\
\hline Medical history & None & None & None & ND & ND & ND \\
\hline $\begin{array}{l}\text { Reported contact } \\
\text { with mollusks }\end{array}$ & ND & ND & ND & ND & ND & ND \\
\hline \multicolumn{7}{|c|}{ Clinical picture } \\
\hline $\begin{array}{l}\text { Duration of } \\
\text { symptoms before } \\
\text { admission }\end{array}$ & 42 days & 1 month & 3 months & ND & ND & ND \\
\hline $\begin{array}{l}\text { Extra-digestive } \\
\text { symptoms }\end{array}$ & $\begin{array}{l}\text { Poor general } \\
\text { condition, slight } \\
\text { fever, constant } \\
\text { crying, anorexia }\end{array}$ & ND & $\begin{array}{l}\text { Poor general } \\
\text { condition, } \\
\text { behavioral } \\
\text { disorders, } \\
\text { prostration }\end{array}$ & ND & ND & ND \\
\hline $\begin{array}{l}\text { Digestive symptoms } \\
\text { \& bleeding }\end{array}$ & $\begin{array}{l}\text { Vomiting, } \\
\text { melena }\end{array}$ & $\begin{array}{l}\text { Abdominal } \\
\text { pain, intestinal } \\
\text { occlusion, } \\
\text { intermittent } \\
\text { rectorrhagia }\end{array}$ & $\begin{array}{l}\text { Intense } \\
\text { abdominal } \\
\text { pain, diarrhea, } \\
\text { melena, } \\
\text { rectorrhagia }\end{array}$ & $\begin{array}{l}\text { Recurrent } \\
\text { gastro- } \\
\text { intestinal } \\
\text { bleeding }\end{array}$ & $\begin{array}{l}\text { Severe right- } \\
\text { lower quadrant } \\
\text { abdominal } \\
\text { pain }\end{array}$ & ND \\
\hline Loss of weight & $25 \%$ & ND & $6 \mathrm{~kg}$ & ND & ND & $\mathrm{ND}$ \\
\hline \multicolumn{7}{|c|}{ Laboratory results } \\
\hline Anemia $(g / d L)$ & 6 & 8.8 & 4.5 & ND & ND & ND \\
\hline $\begin{array}{l}\text { Mean corpuscular } \\
\text { volume (MCV) }\end{array}$ & 67 & ND & 88 & ND & ND & ND \\
\hline Initial WBC (G/L) & 20 & 19 & 26.3 & ND & ND & ND \\
\hline $\begin{array}{l}\text { Initial eosinophilia } \\
(\mathrm{G} / \mathrm{L}(\%))\end{array}$ & $1.46(7 \%)$ & $0.38(2 \%)$ & $2.49(9 \%)$ & ND & ND & $\mathrm{ND}$ \\
\hline $\begin{array}{l}\text { Max. eosinophilia } \\
\text { (G/L) }\end{array}$ & 2.50 & ND & 8.41 & ND & ND & $\mathrm{ND}$ \\
\hline $\begin{array}{l}\text { Angiostrongylus } \\
\text { serodiagnosis }\end{array}$ & ND & ND & ND & ND & No & ND \\
\hline \multicolumn{7}{|c|}{ Abdominal imaging \& surgery } \\
\hline $\begin{array}{l}\text { Exploratory } \\
\text { laparotomy }\end{array}$ & Yes & Yes & No & Yes & Yes & ND \\
\hline Intestinal resection & $5 \mathrm{~cm}$ & $18 \mathrm{~cm}$ (ileum) & Appendix & ND & $\begin{array}{l}12 \mathrm{~cm} \text { (ileo- } \\
\text { ceacum }+ \\
\text { appendix) }\end{array}$ & ND \\
\hline
\end{tabular}


Table 2. (continued).

\begin{tabular}{|c|c|c|c|c|c|c|}
\hline Case & 1 & 2 & 3 & 4 & 5 & 6 \\
\hline \multicolumn{7}{|c|}{ Histology of resected specimen } \\
\hline \multirow[t]{2}{*}{$\begin{array}{l}\text { Histological } \\
\text { examination }\end{array}$} & $\begin{array}{l}\text { Adults, eggs, } \\
\text { and larvae in } \\
\text { ileal biopsy }\end{array}$ & ND & $\mathrm{ND}$ & ND & $\begin{array}{l}\text { Granulomas, } \\
\text { giant cells, } \\
\text { eggs, L1 } \\
\text { larvae, } \\
\text { eosinophilic } \\
\text { infiltration }\end{array}$ & ND \\
\hline & & Diagnos & and medical ca & & & \\
\hline $\begin{array}{l}\text { Anthelmintic } \\
\text { (Thiabendazole) }\end{array}$ & $\begin{array}{l}75 \mathrm{mg} / \mathrm{kg} \text { for } \\
3 \text { days }\end{array}$ & $\begin{array}{l}75 \mathrm{mg} / \mathrm{kg} \text { for } \\
2 \text { days }\end{array}$ & $\begin{array}{l}75 \mathrm{mg} / \mathrm{kg} \text { for } \\
3 \text { days, } 3 \text { times }\end{array}$ & ND & ND & ND \\
\hline Outcome & Recovery & Recovery & Recovery & Recovery & Recovery & Recovery \\
\hline
\end{tabular}

case was defined as a patient with clinical symptoms consistent with HAA and a serum specimen with IgG reactive to Angiostrongylus sp. antigen.

\section{Ethics statement}

The variables were secondarily anonymized and retrospectively collected from medical charts. The French National Committee on Data Protection (CNIL)authorizes the retrospective use of anonymous patient files on the site of patient care in a single hospital.

\section{Results}

During the 18-year period of the study, two confirmed and two probable cases of HAA were identified (male: female 50:50, median age: 7.5 years [min 1 ; max 21 years]). The annual incidence rate was 0.003 cases $/ 100,000$ habitants/year (95 CI\% $=0.00-0.05)$. Most cases $(75 \%)$ were diagnosed during the rainy season. All cases presented abdominal pain associated with high blood eosinophilia (median: $7.24 \mathrm{G} / \mathrm{L}[\min 4.25 ; \max 52.28 \mathrm{G} / \mathrm{L}]$ ). The eosinophilia rate was not related to the severity of the disease. Cases 1 and 2, diagnosed in 12-month old children, were particularly severe and required surgical procedures with diagnostic confirmation by histological findings. These cases were characterized by anemia, a marked loss of weight and the presence of Charcot Leyden crystals in feces. Cases 3 and 4, probable, were diagnosed in a teenager and an adult with serum specimens reactive to Angiostrongylus sp. antigen. The length of hospitalization was variable (median 17.5 days [min 7; max 53 days]) and correlated with disease severity. All cases improved without sequelae. The clinical presentation along with the biological, imaging, histopathological, and epidemiological features are described in Table 1.

\section{Discussion}

Here, we report two confirmed and two probable cases of HAA in Martinique, thus bringing the total number of HAA cases to 10 in the entire Antilles. Indeed, only six sporadic cases of HAA have been reported in the Antilles over the last two decades. Two cases were diagnosed in travelers returning from the Greater Antilles, one from Puerto Rico [47], and the other from the Dominican Republic [59]. In the Lesser Antilles, one case was reported in Martinique in 1988 in a 16-month-old boy [24], followed by two cases in Guadeloupe in 1987 and 1989 in a 20month-old and a five year-old, respectively [26], and a presumed case in the Commonwealth of Dominica in a North-American student in 1997 [50]. Clinical and biological features of these cases are summarized in Table 2 .

In our case series, the diagnosis of angiostrongyliasis was considered after admission to hospital because of the nonspecific clinical presentation of the disease [33]. Symptoms usually include abdominal pain in the right iliac fossa along with fever, anorexia, vomiting, and persistent eosinophilia $(>2 \mathrm{G} / \mathrm{L})$. The disease is generally mild and self-limiting, but some cases can be complicated by intestinal infarction, pseudo-tumor, acute appendicitis, or digestive perforation, requiring emergency laparotomy and surgical care with an unpredictable prognosis [33].

Typically, diagnosis occurs unexpectedly when an exploratory laparotomy or laparoscopy is required with histological examination of unhealthy tissues. Definitive diagnosis is established when histological examination of resected specimens shows eggs, larvae, or adult parasitic forms in mesenteric arteries [19]. In the absence of parasites, histopathological findings can help the diagnosis when they show granulomatous reactions with massive eosinophilic and giant cell infiltration in the intestinal wall and regional lymph nodes and/or eosinophilic vasculitis of arteries, veins, and lymph vessels [19]. In subclinical forms not requiring laparotomy or surgery, diagnosis may be established when IgG anti-crude adult worm antigens are found by ELISA-based serological analysis, but such analyses are available in only a few laboratories worldwide $[1,3,15,48,67]$. Serodiagnosis of $A$. costaricensis is somewhat unsatisfactory because of cross-reactions with $A$. cantonensis, Strongyloides stercoralis, and Gnathostoma spinigerum [47]. Better specificity is observed when antigens are derived from A. costaricensis eggs or the reproductive organs of females $[4,15]$. New tools are now being used to improve the diagnosis in countries in which the disease is endemic, such as Brazil, particularly PCR on paraffin-embedded biopsy tissue or sera, which can lead to 
a $20 \%$ increase in the rate of presumptive diagnoses $[8,53]$. Unfortunately, such biological tools are not yet available in the French territories.

In our study, the pediatric cases (cases 1 and 2) illustrate the severe and chronic form of the disease, with necrotizing intestinal inflammation, requiring laparotomy and partial intestinal resection. These two cases were characterized by weight loss, anemia, and a long hospital stay (Table 1), consistent with the results observed in the three reported pediatric cases in Martinique and Guadeloupe in the 1980's [24,26]. In both of our pediatric cases, examination of the ileo-cecal surgical specimen unexpectedly led to the diagnosis of HAA through microscopic identification of $A$. costaricensis eggs and larvae in the context of a typical, intense ileo-cecal inflammatory, eosinophilic, and granulomatous reaction. Case 1 was particularly intriguing due to the presence of degenerated helminth eggs in the feces after surgery (Fig. 2). We could not confirm them as $A$. costaricensis eggs based solely on morphological observation and molecular investigation was not performed. Indeed, detection of $A$. costaricensis eggs in feces has rarely been described, since their elimination is prevented by the inflammatory reaction in the intestinal wall. However, in this case, surgery may have liberated the eggs in the digestive tract. Cases 3 and 4 illustrate the presumptive and probable diagnoses of less severe forms of HAA, based solely on abdominal symptoms and marked eosinophilia. The absence of histopathological examination of digestive specimens and specific $A$. costaricensis serological and PCR tests in the French territory hampered a definitive diagnosis. The main elements supporting the diagnosis of HAA were the positive results to $A$. cantonensis serological tests (which are often cross-reactive $A$. costaricensis antigens), combined with negative results for serological tests for other parasites. Several negative parasitological examinations of feces and the absence of headaches and neurological symptoms, respectively ruled out a possible differential diagnosis of strongyloidiasis and angiostrongyliasis due to $A$. cantonensis. All patients recovered without sequelae.

There is no consensus concerning the treatment of HAA [38]. It is mainly supportive, focusing on analgesia, hydration, and nutrition. Surgery can solve ischemiarelated intestinal damage and perforation. Anthelmintic treatment using benzimidazole-derived compounds is debatable because their larvicidal effect aggravates the inflammatory response, leading to more severe lesions, and may favor the erratic migration of adult parasites and larvae [39]. Recent studies in mouse models showed that prophylactic enoxaparin treatment does not prevent tissue damage and mortality related to abdominal angiostrongyliasis $[54,55]$. The four patients in our case series were treated with an anthelmintic as standard treatment for cases of high eosinophilia before diagnostic confirmation.

The mode of transmission of HAA varies depending on the geographical area, generally through the slime of mollusks (i.e., mollusks mouthed by young children or in poorly washed vegetables or aromatic plants) or the consumption of raw mollusks (i.e., during atypical medicinal practices) [28]. The mode of transmission for the two confirmed cases is unclear, as no evident contact with mollusks was reported for either patient. However, environmental investigation in one case found the frequent presence of slugs (und. species) near the house, sometimes reaching the bathroom, and the frequent presence of Achatina fulica snails in their favorite strolling zone in the Morne-Rouge district. In the other case, the parents did not exclude contact between their child and mollusks, but no specific event was reported. The modest family house was in a district infested with slugs and snails during the rainy season, including Limicolaria aurora and A. fulica, and surrounded by brush and sugar cane fields with many rodents. These mollusks were not examined to ascertain the presence of A. costaricensis. Aside from the adult case diagnosed during the dry season in February 2017, all diagnoses in children were made during the rainy season, when slugs and snails are abundant. Environmental studies are needed to better understand the routes of HAA transmission and evaluate the infection rate and dissemination in mollusks and rodents in Martinique.

The only environmental investigation in the French Antilles was conducted on Rattus rattus and Rattus norvegicus in Guadeloupe (an island close to Martinique) in 1992 and showed that $7.5 \%$ of rats tested were naturally infected by $A$. costaricensis [25]. These rat species are also found in Martinique and may be the main definitive hosts there [49] (Table 3). Among the most common definitive hosts in South America, the rodent families Cricetidae and Heteromyidae are absent in Martinique [52,61,63]. Slugs, acting as intermediate hosts for A. costaricensis in South America, are also found in Martinique, including the Veronicellidae family (Sarasinula plebeia, Diplosolenodes occidentalis) and limacid slugs $[10,62,63]$ (Table 3 ). The aquatic snails Biomphalaria glabrata and B. straminea could have been a potential intermediate host, but are now considered to have been eradicated in Martinique, following a control program on intestinal parasitosis initiated in 1978 [10,22] (Table 3). Finally, A. fulica snails are not considered to be major intermediate hosts in the wild, although they are capable of hosting $A$. costaricensis larvae in laboratory models [6]. This invasive species, first described in 1989 in Martinique, is responsible for the emergence of central nervous system angiostrongyliasis due to Angiostrongylus cantonensis in the Lesser Antilles [9].

HAA is an emerging parasitic disease in the neotropics, which is not critical in most cases, but nonetheless potentially life-threatening. In Martinique, this zoonosis is sporadic and rare, with an estimated incidence of 0.003 cases $/ 100,000$ habitants/year in this study. However, HAA can be misdiagnosed due to its nonspecific clinical presentation, paucisymptomatic cases, and the lack of awareness and information in the medical community concerning this disease [18]. Eosinophilia of undetermined origin is often treated using empirical anthelmintic 

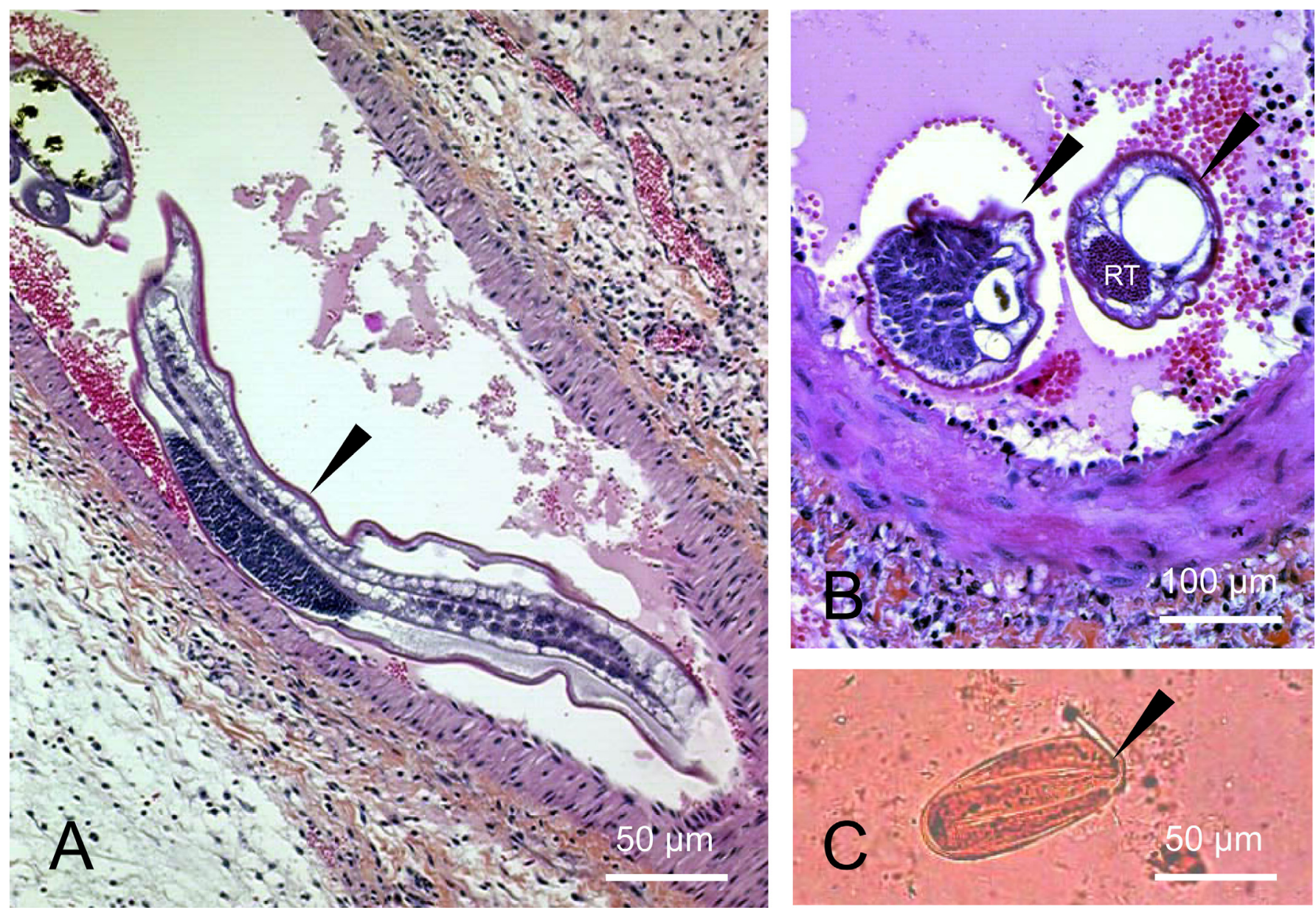

Figure 2. Microscopical aspects of the ileal specimen and parasitic stools examination of case No. 1. A. Longitudinal section of a mesenteric artery with an $A$. costaricensis adult inside arterioles (dart) (HES, 100x). B. Cross section of intra-mesenteric arterial adult nematodes (darts) with an eosinophilic inflammatory infiltrate in the surrounding tissues. One harbors a reproductive tube (RT) (HES, 100x). C. Impaired embryonated egg of nematode (maybe A. costaricensis) (dart) measuring $80 \times 35 \mu \mathrm{m}$ (MIF, 200x) found in stools collected four days after abdominal surgery.
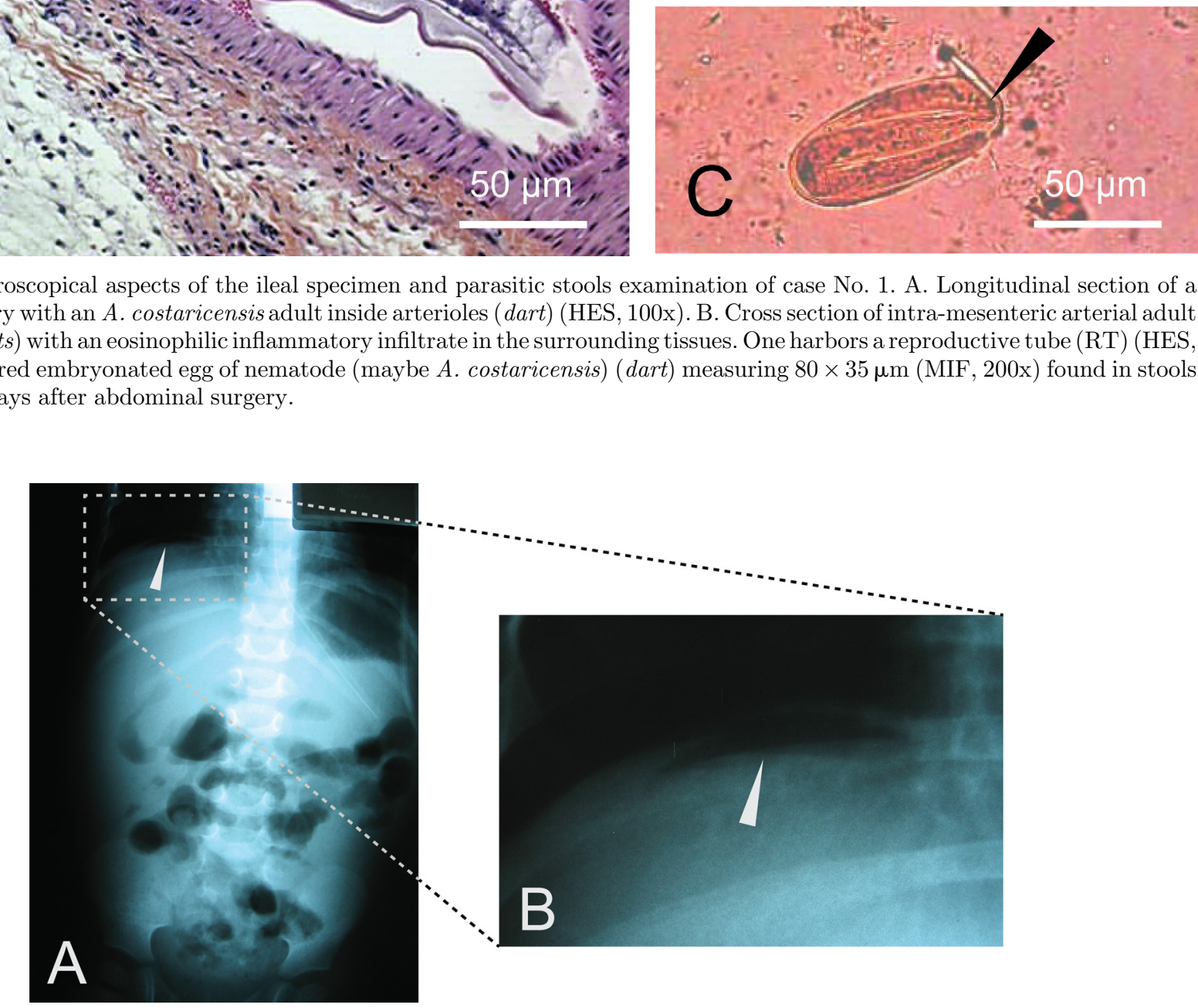

Figure 3. Case No. 2 abdominal X-ray. Imagery was performed 49 days following hospitalization. A. Pneumoperitoneum under the right hypochondria (white arrow). B. Focus on the pneumoperitoneum (white arrow). 
Table 3. A. costaricensis definitive and intermediate hosts described in the literature and comparison with the species found in Martinique. The definitive hosts of $A$. costaricensis in Martinique could be the rodent species Rattus rattus and Rattus norvegicus. The intermediate hosts could be Sarasinula plebeia, Diplosolenodes occidentalis, Deroceras laeve, and Biomphalaria spp.

\begin{tabular}{|c|c|c|c|c|}
\hline \multicolumn{5}{|c|}{ Definitive hosts } \\
\hline Order & Family & Species & Found in Martinique & Countries \& references \\
\hline \multirow{11}{*}{ Rodentia } & \multirow{7}{*}{ Cricetidae } & Sigmodon hispidus & No & $\begin{array}{l}\text { Costa Rica [42], Panama [63], } \\
\text { United States [65] }\end{array}$ \\
\hline & & $\begin{array}{l}\text { Oligoryzomys (=Oryzomys) } \\
\text { fulvescens }\end{array}$ & No & Panama $[63]$ \\
\hline & & Sooretamys angouya & No & Brazil [20] \\
\hline & & $\begin{array}{l}\text { Oligoryzomys nigripes } \\
\text { (=Oryzomys eliurus) }\end{array}$ & No & Brazil [20] \\
\hline & & Zygodontomys microtinus & No & Panama [63] \\
\hline & & Oryzomys caliginosus & No & Colombia [35] \\
\hline & & Akodon montensis & No & Argentina [52] \\
\hline & \multirow{2}{*}{ Muridae } & Rattus rattus & Yes & $\begin{array}{l}\text { Costa Rica [42], Panama [63], } \\
\text { Guadeloupe [25] }\end{array}$ \\
\hline & & Rattus norvegicus & Yes & Guadeloupe [25] \\
\hline & Heteromyidae & Liomys adspersus & No & Panama [63] \\
\hline & Echimyidae & Proechimys sp. & No & Venezuela $[56]$ \\
\hline \multirow[b]{2}{*}{ Carnivora } & \multirow[b]{2}{*}{ Procyonidae } & Nasua narica bullata & No & Costa Rica $[41,42,57]$ \\
\hline & & Procyon lotor & No & United States [40] \\
\hline Didelphimorphia & Didelphidae & Didelphis virginiana & No & United States [40] \\
\hline \multirow{3}{*}{ Primates } & Hylobatidae & Hylobates syndactylus & No & United States [40] \\
\hline & Aotidae & Aotus nancymaae & No & United States [40] \\
\hline & Cebidae & Saguinus mystax & No & Peru [60] \\
\hline \multicolumn{5}{|c|}{ Intermediate hosts (Gastropods) } \\
\hline Class & Family & Species & Found in Martinique & Countries \& references \\
\hline \multirow{11}{*}{ Gastropods: slugs } & \multirow{7}{*}{ Veronicellidae } & $\begin{array}{l}\text { Sarasinula pleibeia } \\
\text { (= Vaginulus plebeius) }\end{array}$ & Yes & Brazil [29], Nicaragua [12] \\
\hline & & Diplosolenodes occidentalis & Yes & Honduras [5] \\
\hline & & Belocaulus angustipes & No & Brazil [51] \\
\hline & & Phyllocaulis variegatus & No & Brazil $[21,51]$ \\
\hline & & Phyllocaulis soleiformis & No & Brazil [51] \\
\hline & & Sarasinula marginata & No & Brazil $[31,37]$ \\
\hline & & Limax maximus & No & Brazil [62] \\
\hline & Limacidae & Limax flavus & No & Brazil [62] \\
\hline & Agriolimacidae & Deroceras laeve & Yes & Brazil [36] \\
\hline & Bradybaenidae & Bradybaena similaris & No & Brazil [51] \\
\hline & Strophocheilidae & Megalobulimus abbreviatus & No & Brazil [62] \\
\hline \multirow[t]{4}{*}{ Gastropods: snails } & \multirow{3}{*}{ Planorbidae } & Biomphalaria glabrata & $\begin{array}{l}\text { Considered eradicated } \\
\text { from Martinique }\end{array}$ & Brazil $[22,32]$ \\
\hline & & Biomphalaria straminea & Yes & Brazil [32] \\
\hline & & Biomphalaria tenagophila & No & Brazil $[2,32]$ \\
\hline & Achatinidae & Achatina fulica ${ }^{\mathrm{a}}$ & Yes & Brazil $[6,16]$ \\
\hline
\end{tabular}

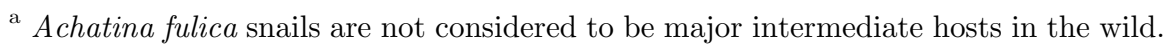

treatment (generally a combination of albendazole or flubendazole and ivermectin) to cover a broad range of parasitic disease etiologies known in Martinique, including ascariasis, enterobiasis, strongyloidiasis, trichuriasis, and ankylostomiasis [14]. The combination of abdominal pain and hypereosinophilia should suggest potential HAA disease as for other well-known intestinal helminthiases, and clinicians should then seek histological or biological 

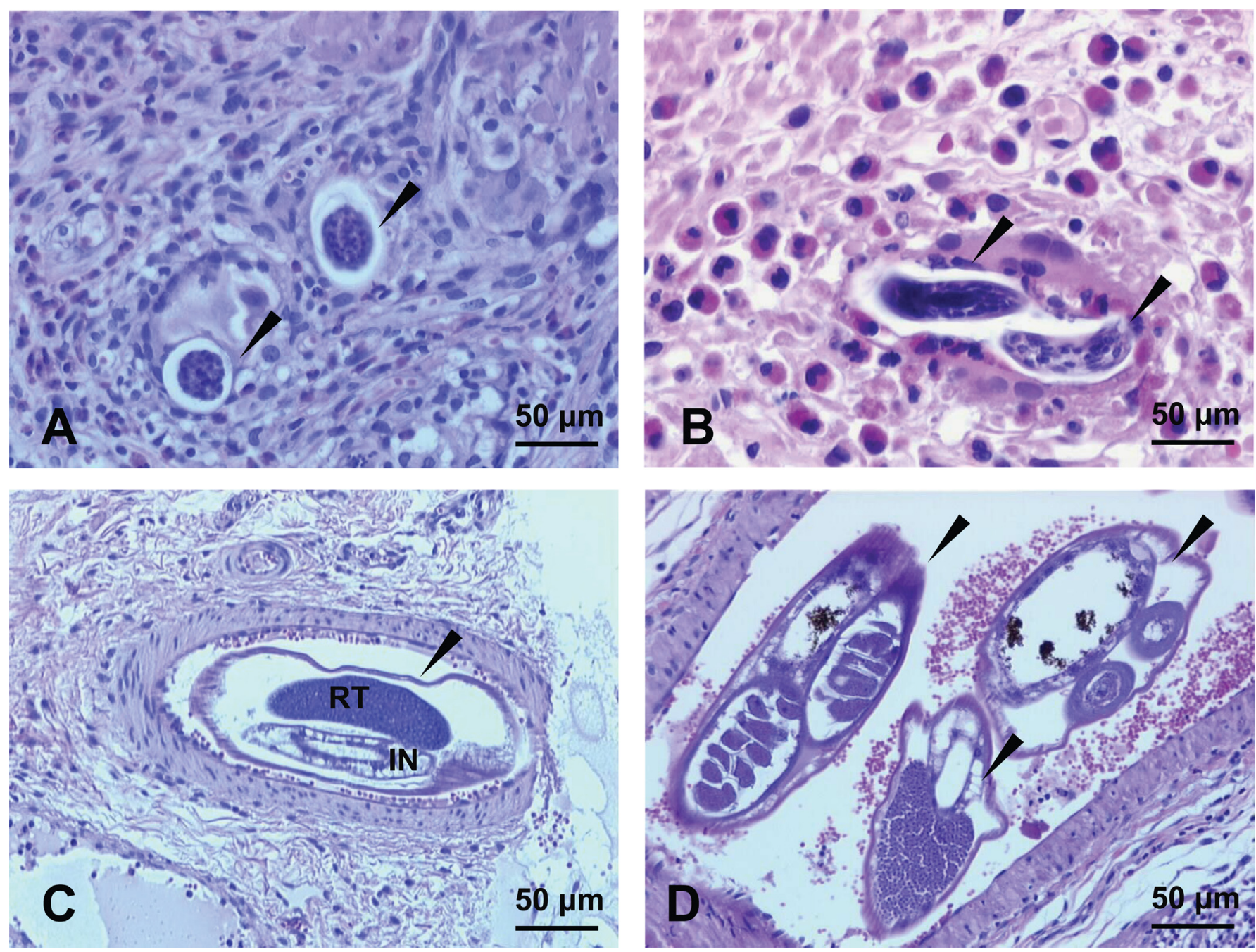

Figure 4. Case No. 2 microscopic aspects of the ileo-colic specimen stained with HES. A. Section of the intestine showing two thinshelled eggs (darts) surrounded by a granulomatous reaction with giant cells (HES, 100x). B. Section of the intestine showing two $A$. costaricensis larvae (darts) surrounded by a granulomatous reaction with giant cells and a considerable number of eosinophils cells (HES, 100x). C. Transversal section of a mesenteric artery showing $A$. costaricensis adult worm (dart) with a single reproductive tube (RT) and intestine (IN) (HES, 100x). D. Transversal section of a mesenteric small artery showing three sections of adult worms (darts) (HES, 100x).

evidence of HAA. Thus, efforts should aim to raise awareness in the medical community and facilitate access to diagnostic tools, including serodiagnosis and PCR-based methods. An epidemiological study focusing on intermediate hosts would lead to a better understanding of disease transmission in Martinique and help establish more efficient prophylactic measures.

Acknowledgments. We thank the team of the University Hospital of Martinique including biologists, anatomopathologists, technicians, pediatricians, and digestive surgeons for initial diagnosis of abdominal angiostrongyliasis. We thank the DRCI of the University Hospital of Martinique and the Laboratories of Basse-Terre, Pointe-à-Pitre, Cayenne, Grenoble Alpes Hospitals, and the Cire Antilles, in particular Dr. Didier Mattera, Dr. Muriel Nicolas, Prof. Magalie Demar, Prof. Hervé Pelloux, Mr. Lyderic Aubert and Mr. Régis Delannoye for their collaboration in the project "Angiostrongylus Research In French Antilles and Guiana". We thank Dr. Beatrice Nickel and Dr. Hanzpeter Marti for performing serological analyses. We also thank Dr. Christopher Swale and Prof. Mathieu Nacher for reviewing the manuscript. The authors declare that they have no conflict of interest.

\section{References}

1. Abrahams-Sandi E, Mesén-Ramírez P, Suarez-Chacón D, Fernández-Quesada K. 2011. An indirect immunofluorescence antibody test employing whole eggs as the antigen for the diagnosis of abdominal angiostrongyliasis. Memórias do Instituto Oswaldo Cruz, 106, 390-393.

2. Banevicius NMS, Zanotti-Magalhães EM, Magalhães LA, Linhares AX. 2006. Behavior of Angiostrongylus costaricensis in planorbids. Brazilian Journal of Biology, 66, 199-204.

3. Ben R, Rodrigues R, Agostini AA, Graeff-Teixeira C. 2010. Use of heterologous antigens for the immunodiagnosis of abdominal angiostrongyliasis by an enzyme-linked immunosorbent assay. Memórias do Instituto Oswaldo Cruz, 105, 914-917. 
4. Bender AL, Maurer RL, da Silva MCF, Ben R, Terraciano PB, da Silva ACA. 2003. Eggs and reproductive organs of female Angiostrongylus costaricensis are more intensely recognized by human sera from acute phase in abdominal angiostrongyliasis. Revista da Sociedade Brasileira de Medicina Tropical, 36, 449-454.

5. Caballero R, Thomé JW, Andrews KL, Rueda A. 1991. Babosas de Honduras (Soleolifera: Veronicellidae): biología, ecología, distribución, descripción, importancia económica, y claves para su identificación. Ceiba, 32, 107-125.

6. Carvalho O dos S, Teles HM, Mota EM, Lafetá C, de Mendonça GF, Lenzi HL. 2003. Potentiality of Achatina fulica Bowdich, 1822 (Mollusca: Gastropoda) as intermediate host of the Angiostrongylus costaricensis Morera \& Céspedes 1971. Revista da Sociedade Brasileira de Medicina Tropical, 36, 743-745.

7. Cespede R, Salas J, Mekbel S, Troper L, Mullner F, Morera P. 1967. Granulomas entéricos y linfaticos con intensa eosinofilia tisular producidos por um estrongilideo (Strongylata). Acta Médica Costarricense, 10, 235-255.

8. Da Silva ACA, Graeff-Teixeira C, Zaha A. 2003. Diagnosis of abdominal angiostrongyliasis by PCR from sera of patients. Revista do Instituto de Medicina Tropical de São Paulo, 45, 295-297.

9. Dard C, Piloquet J-E., Qvarnstrom Y, Fox LM, M'kada H, Hebert J-C., Mattera D, Harrois D. 2017. First evidence of angiostrongyliasis caused by Angiostrongylus cantonensis in Guadeloupe, Lesser Antilles. American Journal of Tropical Medicine and Hygiene, 96, 692-697.

10. Dellanoye R, Charles L, Pointier J, Massemin D. 2015. Sarasinula plebeia, in Mollusques continentaux de la Martinique, Collection Inventaires et biodiversité. Biotope Éditions \& Muséum National d'Histoire Naturelle: Mèze \& Paris. p. 328.

11. Duarte Z, Morera P, Davila P, Gantier JC. 1992. Angiostrongylus costaricensis natural infection in Vaginulus plebeius in Nicaragua. Annales de Parasitologie Humaine et Comparée, 67, 94-96.

12. Duarte Z, Morera P, Vuong PN. 1991. Abdominal angiostrongyliasis in Nicaragua: a clinico-pathological study on a series of 12 cases reports. Annales de Parasitologie Humaine et Comparée, 66, 259-262.

13. Eamsobhana P, Gan XX, Ma A, Wang Y, Wanachiwanawin D, Yong HS. 2014. Dot immunogold filtration assay (DIGFA) for the rapid detection of specific antibodies against the rat lungworm Angiostrongylus cantonensis (Nematoda: Metastrongyloidea) using purified $31-\mathrm{kDa}$ antigen. Journal of Helminthology, 88, 396-401.

14. Edouard A, Edouard S, Desbois N, Plumelle Y, Rat C, Calès-Quist D. 2004. Évolution de la prévalence des parasitoses digestives au CHU de Fort-de-France (Martinique). Presse Médicale, 33, 707-709.

15. Geiger SM, Laitano AC, Sievers-Tostes C, Agostini AA, Schulz-Key H, Graeff-Teixeira C. 2001. Detection of the acute phase of abdominal angiostrongyliasis with a parasitespecific IgG enzyme linked immunosorbent assay. Memórias do Instituto Oswaldo Cruz, 96, 515-518.

16. Graeff-Teixeira C. 2007. Expansion of Achatina fulica in Brazil and potential increased risk for angiostrongyliasis. Transactions of the Royal Society of Tropical Medicine and Hygiene, 101, 743-744.

17. Graeff-Teixeira C, Agostini AA, Camillo-Coura L, Ferreirada-Cruz MF. 1997. Seroepidemiology of abdominal angiostrongyliasis: the standardization of an immunoenzymatic assay and prevalence of antibodies in two localities in southern Brazil. Tropical Medicine \& International Health, $2,254-260$.
18. Graeff-Teixeira C, Camillo-Coura L, Lenzi HL. 1987. Abdominal angiostrongyliasis - an under-diagnosed disease. Memórias do Instituto Oswaldo Cruz, 82, 353354.

19. Graeff-Teixeira C, Camillo-Coura L, Lenzi HL. 1991. Histopathological criteria for the diagnosis of abdominal angiostrongyliasis. Parasitology Research, 77, 606-611.

20. Graeff-Teixeira C, de Avila-Pires FD, Machado R de C, Camillo-Coura L, Lenzi HL. 1990. Identification of wild rodents as hosts of Angiostrongylus costaricencis in southern Brazil. Revista do Instituto de Medicina Tropical de São Paulo, 32, 147-150.

21. Graeff-Teixeira C, Thomé JW, Pinto SC, Camillo-Coura L, Lenzi HL. 1989. Phyllocaulis variegatus-an intermediate host of Angiostrongylus costaricensis in south Brazil. Memórias do Instituto Oswaldo Cruz, 84, 65-68.

22. Guerino LR, Carvalho JF, Magalhães LA, Zanotti-Magalhães EM. 2017. Susceptibility of Biomphalaria glabrata submitted to concomitant infection with Angiostrongylus costaricensis and Schistosoma mansoni. Brazilian Journal of Biology, 77, 451-458.

23. Incani RN, Caleiras E, Martín M, González C. 2007. Human infection by Angiostrongylus costaricensis in Venezuela: first report of a confirmed case. Revista do Instituto de Medicina Tropical de São Paulo, 49, 197-200.

24. Jeandel R, Fortier G, Pitre-Delaunay C, Jouannelle A. 1988. Angiostrongylase intestinale à Angiostrongylus costaricencis. À propos d'un cas en Martinique. Gastroentérologie Clinique et Biologique, 12, 390-393.

25. Juminer B, Borel G, Mauleon H, Durette-Desset MC, Raccurt CP, Roudier M. 1993. L'infection murine naturelle par Angiostrongylus costaricensis Morera et Céspedes, 1971 à la Guadeloupe. Bulletin de la Société de Pathologie Exotique, 86, 502-505.

26. Juminer B, Roudier M, Raccurt CP, Pujol HP, Gerry F, Bonnet R. 1992. Présence d'angiostrongylose en Guadeloupe. À propos de deux cas récents. Bulletin de la Société de Pathologie Exotique, 85, 39-43.

27. Kaminsky R, Caballero R, Andrews K. 1995. Presencia de Angiostrongylus costaricensis en Honduras y sus relaciones agro-ecologicas y humanas. Parasitologia al Dia, 19, 81-90.

28. Kramer MH, Greer GJ, Quiñonez JF, Padilla NR, Hernández B, Arana BA. 1998. First reported outbreak of abdominal angiostrongyliasis. Clinical Infectious Diseases, $26,365-372$.

29. Laitano AC, Genro JP, Fontoura R, Branco SS, Maurer RL, Graeff-Teixeira C. 2001. Report on the occurrence of Angiostrongylus costaricensis in southern Brazil, in a new intermediate host from the genus Sarasinula (Veronicellidae, Gastropoda). Revista da Sociedade Brasileira de Medicina Tropical, 34, 95-97.

30. Lasso R. 1985. Angiostrongiliasis en Ecuador. Universidad de Guayaquil Comisión de Ciencia y Tecnología Boletín informativo. N. 3.

31. Lima LC, Massara CL, de Souza CP, Jannotti-Passos LK, Lenzi HL. 1992. Sarasinula marginata (Semper, 1885) (Mollusca, Soleolifera) from Belo Horizonte (MG, Brasil) as a potential intermediate host of Angiostrongylus costaricensis Morera, Cespedes, 1971. Revista do Instituto de Medicina Tropical de São Paulo, 34, 117-122

32. Lima LC, Massara CL, de Souza CP, Vidigal TD, Lenzi HL, Carvalho O dos S. 1992. The susceptibility of Planorbidae from the metropolitan area of Belo Horizonte, MG (Brazil) to Angiostrongylus costaricensis (Nematoda, Angiostrongylidae). Revista do Instituto de Medicina Tropical de São Paulo, 34, 399-402. 
33. Loría-Cortés R, Lobo-Sanahuja JF. 1980. Clinical abdominal angiostrongylosis. A study of 116 children with intestinal eosinophilic granuloma caused by Angiostrongylus costaricensis. American Journal of Tropical Medicine and Hygiene, 29, 38-44.

34. Maldonado A, Simoes R, Thiengo S. 2012. Angiostrongyliasis in the Americas, in Zoonosis, Editor. Lorenzo-Morales J, Rijeka, Croatia. p. 303-320.

35. Malek EA. 1981. Presence of Angiostrongylus costaricensis Morera and Céspedes 1971 in Colombia. American Journal of Tropical Medicine and Hygiene, 30, 81-83.

36. Maurer RL, Graeff-Teixeira C, Thome JW, Chiaradia LA, Sugaya H, Yoshimura K. 2002. Natural infection of Deroceras laeve (Mollusca: gastropoda) with metastrongylid larvae in a transmission focus of abdominal angiostrongyliasis. Revista do Instituto de Medicina Tropical de São Paulo, 44, 53-54

37. Mendonca CLGF, Carvalho OS, Lenzi HL. 2002. Angiostrongylus costaricensis life cycle in the intermediate host Sarasinula marginata Semper, 1885 (Mollusca: Soleolifera). Revista da Sociedade Brasileira de Medicina Tropical, 35, 199-200.

38. Mentz MB, Graeff-Teixeira C. 2003. Drug trials for treatment of human angiostrongyliasis. Revista do Instituto de Medicina Tropical de São Paulo, 45, 179-184.

39. Mentz MB, Graeff-Teixeira C, Garrido CT. 2004. Treatment with mebendazole is not associated with distal migration of adult Angiostrongylus costaricensis in the murine experimental infection. Revista do Instituto de Medicina Tropical de São Paulo, 46, 73-75.

40. Miller CL, Kinsella JM, Garner MM, Evans S, Gullett PA, Schmidt RE. 2006. Endemic infections of Parastrongylus (=Angiostrongylus) costaricensis in two species of nonhuman primates, raccoons, and an opossum from Miami, Florida. Journal of Parasitology, 92, 406-408.

41. Monge E, Arroyo R, Solano E. 1978. A new definitive natural host of Angiostrongylus costaricensis (Morera and Céspedes 1971). Journal of Parasitology, 64, 34.

42. Morera P. 1970. Studies of the definitive host of Angiostrongylus costaricensis (Morera and Céspedes, 1971). Boletín Chileno de Parasitología, 25, 133-134.

43. Morera P. 1985. Abdominal angiostrongyliasis: a problem of public health. Parasitology Today, 1, 173-175.

44. Morera P. 1973. Life history and redescription of Angiostrongylus costaricensis Morera and Céspedes, 1971. American Journal of Tropical Medicine and Hygiene, 22, 613-621.

45. Morera P. 1967. Granulomas entericos y linfaticos con intensa eosinophilia tisular producidos por um estrongilideo (Strongylata; Raillet y Henry, 1913): II. Aspectos parasitologico. Acta Médica Costarricence, 10, 257-265.

46. Morera P, Andrews KL, Rueda A. 1988. The intermediate host of Angiostrongylus costaricensis in Honduras. Revista de Biología Tropical, 36, 575-576.

47. Neafie R, Marty A. 1993. Unusual infections in humans. Clinical Microbiology Reviews, 6, 34-56.

48. Palominos PE, Gasnier R, Rodriguez R, Agostini AA, GraeffTeixeira C. 2008. Individual serological follow-up of patients with suspected or confirmed abdominal angiostrongyliasis. Memórias do Instituto Oswaldo Cruz, 103, 93-97.

49. Pascal M, Lorvelec O, Borel G, Rosine A. 2004. Structures spécifiques des peuplements de rongeurs d'agro-écosystèmes et d'écosystèmes "naturels" de la Guadeloupe et de la Martinique. Revue d'Écologie - La Terre et la Vie, 59, 283-292.
50. Raccurt CP. 1997. Deux angiostrongyloses murines dans la Caraïbe et leurs conséquences humaines : une menace pour Haïti? Médecine Tropicale: Revue du Corps de Santé Colonial, 57, 412-413.

51. Rambo PR, Agostini AA, Graeff-Teixeira C. 1997. Abdominal angiostrongylosis in southern Brazil-prevalence and parasitic burden in mollusc intermediate hosts from eighteen endemic foci. Memórias do Instituto Oswaldo Cruz, 92, 9-14.

52. Robles M del R, Kinsella JM, Galliari C, Navone GT. 2016. New host, geographic records, and histopathologic studies of Angiostrongylus spp (Nematoda: Angiostrongylidae) in rodents from Argentina with updated summary of records from rodent hosts and host specificity assessment. Memórias do Instituto Oswaldo Cruz, 111, 181-191.

53. Rodriguez R, da Silva ACA, Müller CA, Alves SL, GraeffTeixeira C, Fornari F. 2014. PCR for the diagnosis of abdominal angiostrongyliasis in formalin-fixed paraffinembedded human tissue. PLoS ONE, 9, e93658.

54. Rodriguez R, Porto SM, Dos Santos Ferrari R, Marcolan AM, da Silva ACA, Graeff-Teixeira C. 2011. Outcomes in mice with abdominal angiostrongyliasis treated with enoxaparin. Parasitology Research, 109, 787-792.

55. Sandri ASS, Rodriguez R, Costa MM, Porto SM, Schwingel D, Vieira MIB. 2018. High-dose enoxaparin in the treatment of abdominal angiostrongyliasis in Swiss mice. Journal of Helminthology, doi: 10.1017/S0022149X17000852.

56. Santos CP. 1985. Redescrição de Angiostrongylus (Parastrongylus) costaricensis isolado de novo hospedeiro silvestre, Proechimys sp., na Venezuela (Metastrongyloidea, Angiostrongylidae). Memórias do Instituto Oswaldo Cruz, 80, 81-83

57. Santoro M, Alfaro-Alarcón A, Veneziano V, Cerrone A, Latrofa MS, Otranto D. 2016. The white-nosed coati ( Nasua narica) is a naturally susceptible definitive host for the zoonotic nematode Angiostrongylus costaricensis in Costa Rica. Veterinary Parasitology, 228, 93-95.

58. Sierra E, Morera P. 1968. Angiostrongilosis abdominal. Primer caso humano encontrado em Honduras (Hospital Evangélico de Siguatepeque). Acta Médica Costarricense, $15,95-99$.

59. Silvera CT, Ghali VS, Roven S, Heimann J, Gelb A. 1989. Angiostrongyliasis: a rare cause of gastrointestinal hemorrhage. American Journal of Gastroenterology, 84, 329-332.

60. Sly DL, Toft JD, Gardiner CH, London WT. 1982. Spontaneous occurrence of Angiostrongylus costaricensis in marmosets (Saguinus mystax). Laboratory Animal Science, 32, 286-288.

61. Spratt DM. 2015. Species of Angiostrongylus (Nematoda: Metastrongyloidea) in wildlife: A review. International Journal for Parasitology. Parasites and Wildlife, 4, $178-189$

62. Teixeira CG, Thiengo SC, Thome JW, Medeiros AB, Camillo-Coura L, Agostini AA. 1993. On the diversity of mollusc intermediate hosts of Angiostrongylus costaricensis Morera \& Cespedes, 1971 in southern Brazil. Memórias do Instituto Oswaldo Cruz, 88, 487-489.

63. Tesh RB, Ackerman LJ, Dietz WH, Williams JA. 1973. Angiostrongylus costaricensis in Panama. Prevalence and pathologic findings in wild rodents infected with the parasite. American Journal of Tropical Medicine and Hygiene, 22, 348-356.

64. Ubelaker JE, Hall NM. 1979. First report of Angiostrongylus costaricensis Morera and Céspedes 1971 in the United States. Journal of Parasitology, 65, 307. 
65. Vuong PN, Brama $\mathrm{P}$, Bonète R, Houissa-Vuong $\mathrm{S}$, Catanzano-Laroudie M, Baviera E. 2002. Necrotic eosinophilic angiitis with ileal perforation and peritonitis secondary to abdominal angiostrongyliasis. Presse Médicale, 31, 1700-1703.

66. Wang Q-P., Lai D-H., Zhu X-Q., Chen X-G., Lun Z-R. 2008. Review: Human angiostrongyliasis. Lancet Infectious diseases, 8, 621-630.

67. Wilkins PP, Qvarnstrom Y, Whelen AC, Saucier C, da Silva AJ, Eamsobhana P. 2013. The current status of laboratory diagnosis of Angiostrongylus cantonensis infections in humans using serologic and molecular methods. Hawaii Journal of Medicine \& Public Health, $72,55-57$.
68. Wu SS, French SW, Turner JA. 1997. Eosinophilic ileitis with perforation caused by Angiostrongylus (Parastrongylus) costaricensis. A case study and review. Archives of Pathology \& Laboratory Medicine, 121, 989-991.

69. Zambrano Z. 1973. Ileocolitis pseudotumoral eosinofílica de origen parasitario. Revista Latinoamericana de Patología, $12,43-50$.

70. Zavala Velazquez J, Ramirez Baquedano W, Reyes Perez A, BatesFlores M. 1974. Angiostrongilosis costaricensis. Primeros casos mexicanos. Revista de Investigación Clínica, 26, 389-394.

71. Zilioto A, Kunzle J, Rus Fernandes L, Prates-Campos C, Britto-Costa R. 1975. Angiostrongilíase: apresentação de um provável caso. Revista do Instituto de Medicina Tropical de São Paulo, 17, 312-318.

Cite this article as: Dard C, Nguyen D, Miossec C, de Meuron K, Harrois D, Epelboin L, Cabié A, Desbois-Nogard N. 2018.

Angiostrongylus costaricensis infection in Martinique, Lesser Antilles, from 2000 to 2017. Parasite 25, 22

\section{O PARASTE}

An international open-access, peer-reviewed, online journal publishing high quality papers on all aspects of human and animal parasitology

Reviews, articles and short notes may be submitted. Fields include, but are not limited to: general, medical and veterinary parasitology; morphology, including ultrastructure; parasite systematics, including entomology, acarology, helminthology and protistology, and molecular analyses; molecular biology and biochemistry; immunology of parasitic diseases; host-parasite relationships; ecology and life history of parasites; epidemiology; therapeutics; new diagnostic tools.

All papers in Parasite are published in English. Manuscripts should have a broad interest and must not have been published or submitted elsewhere. No limit is imposed on the length of manuscripts.

Parasite (open-access) continues Parasite (print and online editions, 1994-2012) and Annales de Parasitologie Humaine et Comparée (1923-1993) and is the official journal of the Société Française de Parasitologie. 